\title{
PERTANGGUNGJAWABAN MAKELAR DAN KOMISIONER KEPADA PIHAK KETIGA BERDASARKAN HUKUM DAGANG INDONESIA
}

\author{
Ayu Putri Rainah Petung Banjaransari \\ Fakultas Hukum, Universitas Negeri Semarang \\ rainaascal22@students.unnes.ac.id
}

\begin{abstract}
ABSTRAK
Broker dan Komisaris sebagai pedagang perantara memiliki perbedaan yang signifikan dalam hal kewajiban kepada pihak ketiga, selain memiliki kesamaan dalam hal tujuan. Masing-masing pedagang perantara ini memiliki tanggung jawab dan aturan tersendiri dalam menjalankan tugas dan kewajibannya atas barang atau jasa yang cacat dan tidak aman hukum. Penelitian ini bertujuan untuk secara khusus membahas dan menganalisis kedua pekerjaan tersebut sebagai pedagang perantara dalam ranah ilmu hukum karena kesalahan sering terjadi. Penelitian ini menggunakan metode normatif dengan pendekatan deskriptif dan kualitatif berdasarkan sumber pustaka dan data-data penelitian yang sudah ada. Setelah melalui pembahasan, analisis, dan perbandingan, diperoleh temuan mengenai persamaan broker dan komisaris ditinjau dari tujuan dan esensinya. Selain itu, diperoleh pula temuan perbedaan pertanggungjawaban antara broker dan komisaris sehingga berdampak berbeda pada suatu perikatan.
\end{abstract}

Kata kunci: Broker, Komisaris, Tanggung jawab.

\begin{abstract}
Brokers and Commissioners as intermediary traders have significant differences in terms of obligations to third parties, apart from having similarities in terms of objectives. Each of these intermediate traders has their own responsibilities and rules in carrying out their duties and obligations for goods or services that are defective and legally unsafe. This study aims to specifically discuss and analyze the two jobs as intermediary traders in the realm of legal science because errors often occur. This study uses a normative method with descriptive and qualitative approaches based on existing literature sources and research data. After going through discussion, analysis, and comparison, findings were obtained about the similarities between brokers and commissioners in terms of their objectives and essence. Apart from that, it was also found that there were differences in accountability between brokers and commissioners, which resulted in different impacts on an engagement.
\end{abstract}

Keywords: Broker, Commissioner, Responsibility. 


\section{Latar Belakang}

Setiap kegiatan atau perbuatan perdagangan pastilah menerapkan beberapa prinsip ekonomi yang merupakan faktor yang paling penting bagi para pelaku usaha dalam berusaha. Salah satu dari beberapa prinsip tersebut adalah prinsip penghasilan semaksimal mungkin dengan pengeluaran seminimal mungkin (Perusahaan, n.d.). Adapun yang dimaksud pengeluaran seminimal mungkin di sini adalah pengeluaran berupa perhitungan biaya (seperti bahan dasar, peralatan, perlengkapan, dan bahan setengah jadi) dan perhitungan waktu (misalnya target pemasaran). Para pelaku usaha harus memikirkan metode atau cara yang paling efektif dan efisien agar waktu dan biaya yang akan dimanfaatkan dalam kegiatan usaha menjadi sehemat mungkin. (Syarifin \& Jubaedah, 2012) Dengan demikian satu hal demi tujuan penghematan pengeluaran atas perhitungan akumulatif biaya dan waktu, maka dalam hal ini peran perantara atau penghubung sangat dibutuhkan.

Sebelum memasuki pengenalan secara luas tentang pedagang perantara, berikut ini disajikan beberapa hal terkait kerangka konseptual tentang pedagang, perbuatan perniagaan, dan tanggung jawab. Menurut Pasal 2 Kitab Undang-Undang Hukum Dagang (KUHD) lama, yang dimaksud sebagai pedagang adalah mereka atau orangorang yang menjalankan kegiatan perdagangan sebagai pekerjaannya sehari-hari. Sedangkan yang dimaksud dengan perbuatan perniagaan atau disebut sebagai kegiatan perdagangan dalam Pasal 3 Kitab Undang-Undang Hukum Dagang (KUHD) lama adalah perbuatan pembelian barang untuk dapat dijual kembali. (S- et al., n.d.) Konsepsi mengenai pengertian perbuatan perdagangan tersebut jangan sampai dijadikan sebagai patokan atau pedoman untuk menjalankan usaha di masa sekarang ini. Perbuatan perdagangan tidak secara mutlak membeli barang untuk kemudian dijual kembali, tetapi lebih berfokus kepada pembelian barang itu sendiri.

Kata tanggung jawab selalu dikaitkan dengan kata ganti rugi, yang dimaksud di sini adalah ganti rugi oleh penyandang hak dan kewajiban atas suatu perbuatan yang berbau hukum. Pihak-pihak yang dinyatakan sebagai pihak-pihak yang telah menyebabkan kerugian adalah mereka yang telah melakukan peristiwa hukum baik di dalam maupun di luar kesalahannya 
dan memunculkan akibat dari peristiwa yang mereka lakukan itu, yaitu suatu beban tanggung jawab.(Hughes, 2008) Apabila perbuatan pihak yang bersangkutan menyebabkan kerugian terhadap pihak lain dan ternyata perbuatan itu di luar kesalahannya, hukum dapat secara adil membebaskannya dari beban tanggung jawab, namun dalam hal ini tidak mutlak sifatnya. Hukum tetap dapat mewajibkan pihak yang bersangkutan untuk melakukan tindakan ganti rugi terhadap pihak yang menderita (pihak yang mengalami kerugian atau biasa disebut dengan korban), yang tergantung pada kesepakatan yang telah dibuat sebelum perbuatan hukum itu terjadi. Akan tetapi, kewajiban ganti rugi itu tidak sepenuhnya disebut sebagai ganti rugi, melainkan dikenal dengan sebutan risiko yang menimpa pihak-pihak atas benda-benda yang terkait.(Francisco, A. R. L. (2013). 済無No Title No Title. Journal of Chemical Information and Modeling, 53(9), 2013)

\section{Istilah kerugian biasa} digunakan untuk menjelaskan keadaankeadaan yang tidak menguntungkan baik bagi pihak penjual maupun pembeli. Benda dikatakan mengandung nilai rugi di dalamnya bilamana terdapat hal-hal yang membuat nilai benda tersebut berkurang, misalnya saja cacat (yang dapat dilihat atau yang aman tersembunyi).(Kandjani et al., 2012) Cacat di sini dapat disebabkan oleh cacat yang sejak dari penjual sudah dalam keadaan cacat kemudian penjual dan pembeli sama-sama tidak teliti dan tidak mengetahuinya atau cacat yang dikarenakan saat pendistribusian barang oleh para pedagang perantara yang bersangkutan tidak hati-hati dalam menjalankan tugasnya. Barang-barang seperti ini seharusnya diketahui secara cermat sebelum terjadinya suatu kesepakatan di antara penjual dan pembeli. Begitu juga dengan pedagang perantara, mereka juga harus dengan saksama meneliti kondisi barang sebelum dan sesudah proses penyaluran ke pembeli.(Ningsih, n.d.)

Barang yang cacat memiliki hubungan sebab dan akibat dengan fakta tidak aman hukum. Barang tersebut tidak aman hukum sejak diketahui bahwa barang tersebut cacat dan menjadi permasalahan bagi orang yang akan menerimanya kelak (dalam hal ini pembeli atau pihak ketiga yang telah memiliki kesepakatan dengan penjual). Tindakan yang harus segera dilakukan adalah kedua pihak (penjual 
dan pembeli atau pihak ketiga) bertemu secara langsung atau melalui perantara untuk menyelesaikan kesalahpahaman atau permasalahan yang terjadi di anatara keduanya.(Yepes-Rios et al., 2015) Hal ini dilakukan agar citra perusahaan atau penjual tidak tercoret dari sisi kanan masyarakat atau pembeli lain. Faktanya, berita apapun cepat sekali menyebar, tanpa mengenal kebenaran berita tersebut.

Dari beberapa hal mengenai kerangka konseptual (pedagang, perbuatan perniagaan, dan tanggung jawab) yang telah dijelaskan sebelumnya, di sini dapat bahwa ketiga hal tersebut berkaitan satu sama lain. Akibatnya, ketiga hal tersebut memiliki relasi erat yang berbau hukum atau peristiwa hukum. Adapun pedagang yang dimaksud di sini dapat berarti luas atau berbentuk bermacam-macam sesuai dengan bidang di mana ia dapat secara professional bekerja.(Aytac et al., 2012) Misalnya saja, di kegiatan sehari-hari dapat ditemui banyak jenis pedagang, mulai dari pedagang keliling, pedagang eceran, sales, atau pedagang yang menjual dagangannya di toko atau warung di depan rumahnya. Kemudian, pedagang yang dimaksud untuk pembahasan berikut ini adalah pedagang yang dapat menjadi penghubung antara pedagang (dalam hal ini pengusaha atau pemilik), kegiatan perdagangan (jual beli secara tunai atau kredit, atau kegiatan perniagaan lainnya), dan tanggung jawab dari adanya perbuatan-perbuatan tersebut dalam hal menjalankan tugasnya sebagai penyalur penyelesaian atas permasalahan yang sedang terjadi atau perjanjian yang akan dilakukan.

Lembaga yang menjadi salah satu penopang kegiatan usaha para pelaku usaha disebut sebagai pedagang perantara. Pedagang perantara atau yang biasa disebut sebagai broker menjalankan tugasnya sebagai penghubung atau penyalur hubungan antara produsen dan konsumen. Ia juga dikenal sebagai sebuah agensi atau pemasar dalam kegiatan pemasaran. Dalam hal ini juga dikenal istilah principal, yakni pengusaha atau pemilik perusahaan yang memberikan kuasa kepada penerima kuasa. Adapun si penerima kuasa disebut dengan istilah agent yang harus memenuhi syarat-syarat tertentu yang telah disepakati bersama antara pemberi kuasa dan penerima kuasa.(Christopoulos \& Ingold, 2011) Dari beberapa istilah tersebut dapat ditarik sebuah kesimpulan bahwa 
pedagang perantara hadir sebagai hasil perjanjian atau penyerahan kuasa dari pemberi kuasa kepada penerima kuasa.

Setiap pelaku usaha atau pemilik perusahaan pastilah dan akanselalu mengharapkan manfaat atau hubungan timbal balik yang menguntungkan dari adanya kerja sama dengan pedagang perantara. Manfaat yang jelas terlihat adalah para pelaku usaha dapat menghemat pengeluaran atas perhitungan biaya dan waktu. Tidak hanya itu, pihak-pihak dalam departemen marketing atau departemen lain suatu perusahaan dapat memfokuskan tugasnya ke bagian intern perusahaan karena tugas eksternalnya telah dibebankan kepada pedagang perantara tersebut.(Yustiana et al., 2010) Adapun manfaat lainnya adalah nilai praktis yang timbul setelahnya, yaitu para pelaku usaha dapat langsung menunjuk lembaga perantaraan mana yang akan mereka jalin kerja samanya. Ditambah lagi, wilayah Indonesia yang sangat luas akan menjadi hambatan waktu untuk mengadakan perjanjian secara langsung antara dua pihak yang berkepentingan dalam kegiatan usaha sehingga disinilah manfaatnya menjalin kerja sama dengan pedagang perantara.(Swastiwi, n.d.)
Kehadiran pedagang perantara memiliki beberapa arti penting tersendiri dalam kegiatan perniagaan selain beberapa manfaat yang dapat dirasakan seperti yang telah dijelaskan di paragraf sebelumnya. Pertama, diperlukannya pedagang perantara adalah disebabkan oleh jarak yang kadang tidak dapat diperkirakan jauhnya antara pembeli dan penjual seperti yang dipaparkan dalam tulisan di atas.(Jurnal Law Review - Vol. 3 No. 1, Februari 2014 71, 2014) Arti penting kedua adalah produsen yang tidak mengetahui atau belum mengetahui pembeli dan sebaliknya sehingga keberadaan pedagang perantara sangat penting apaadanya. Kemudian, arti penting ketiga adalah penting ketika para pelaku usaha sangat ingin menjalin kerja sama dengan pihak ketiga yang dimaksud, baik dalam keadaan yang mendesak maupun dalam keadaan yang normal. Terakhir, pentingnya akan suatu kehadiran pedagang perantara adalah saat para pihak berada dalam masalah, broker dapat berperan sebagai penengah atas permasalahan antara pembeli dan penjual.(Timur, 2002)

Pedagang perantara dapat dibedakan menjadi tiga bilik. Bilik pertama adalah pedagang perantara 
berdasarkan hubungan kerja, seperti luar sana yang masih salah dalam pedagang keliling, pengurus filial, mengartikan makelar dan komisioner pemegang prokurasi, pemimpin dalam menjalankan tugas atau perusahaan; bilik kedua adalah usaha kewajibannya. Pada hakikatnya, penjualan langsung; dan adapun bilik makelar dan komisioner adalah pihakketiga adalah pedagang perantara yang pihak perantara atau penghubung berdiri sendiri, seperti makelar, antara pemberi kuasa atau prinsipal dan komisioner, perwakilan perusahaan pihak ketiga dengan tujuan untuk asing, agen perdagangan, pedagang menjalankan perusahaan. Akan tetapi, perantara efek, pialang berjangka, dan dalam Pasal 1 Angka 1 RUU tentang pedagang perantara property (Melvin Keperantaraan(Perusahaan, \& Wen, 2013). Para pedagang n.d.)dijelaskan bahwa keperantaraan perantara tersebut mewakili suatu merupakan perjanjian antara penerima pelaku usaha dalam melakukan kuasa yang melakukan perikatan hubungan kerja sama dengan dengan pemberi kuasa untuk perusahaan, badan hukum, badan melakukan pekerjaan atau jasa bagi usaha, persekutuan, atau para pelaku kepentingan pemberi kuasa. Hal yang usaha lain dengan cara menjalin atau tersebut dijelaskan kemudian dapat membuat perjanjian kerja sama berupa dikatakan sebagai ketidakkonsistenan perjanjian jual beli barang dagangan, RUU dalam penggunaan istilah mengusahakan diskonto, pengangkutan keperantaraan. Mengapa dikatakan dengan kapal, maupun perjanjian demikian? Karena seringkali RUU lainnya. Mereka dalam menjalankan menyebutkan tugas atau kewajiban tugas dan kewajibannya bertindak atau perantara itu sebagai pihak yang berlaku sebagai perantara atau melakukan perikatan, padahal tugas penghubung antara produsen dan atau kewajiban dari pedagang perantara konsumen. Jadi, segala tindakan yang (khususnya makelar dan komisioner) dilakukannya sangat berpengaruh itu adalah mengadakan perjanjian terhadap kesuksesan atau kelangsungan dengan pihak ketiga bagi usaha pemberi kuasanya.

kebermanfaatan perusahaan.

Dua dari banyak macam produk pedagang perantara adalah makelar dan komisioner di mana banyak orang di Makelar dan komisioner (begitu pula dengan jenis pedagang perantara lain) tidak akan membutuhkan modal 
yang banyak dalam menjalankan kegiatannya. Mereka cukup menjadi asisten atau pembantu di luar perusahaan yang bekerja untuk keperluan eksternal perusahaan guna memperoleh provisi. Sementara kondisi yang sesungguhnya, banyak sekali pihak-pihak misalnya pelaku usaha, pedagang perantara, pihak ketiga yang terjebak dalam berbagai kesulitan atau masalah di perusahaan.(S- et al., n.d.) Kesulitankesulitan tersebut misalnya saja adalah pihak ketiga dalam kondisi yang tidak menguntungkan, baik berupa menerima kecacatan barang-barang yang dibelinya maupun tidak aman secara hukum barang-barang yang dibelinya. Pada akhirnya, seringkali tanggung jawab atas beberapa masalah tersebut dilimpahkan atau dipindahtangankan kepada pelaku usaha (pemberi kuasa atau dikenal juga dengan istilah principal) ataupun sebaliknya, yakni beberapa masalah tersebut dibebankan kepada pedagang perantara (penerima kuasa)(Timur, 2002).

Hal-hal yang akan dijelaskan kemudian dalam tulisan ini memiliki tujuan untuk mempermudah dan memperjelas pembahasan. Selain itu, tulisan ini juga bertujuan untuk menguraikan dengan jelas fakta yang terjadi di lapangan dalam kegiatan usaha perniagaan di Indonesia. Berikut ini adalah dua hal yang akan dibahas mengenai permasalahan yang telah digambarkan dalam latar belakang tersebut di atas:

1) Bagaimanakah hubungan hukum makelar dan komisioner terhadap pihak ketiga?
2) Apa perbedaan bentuk pertanggungjawaban antara makelar dan komisioner terhadap pihak ketiga?

\section{Metode Penelitian}

Penelitian ini menggunakan metode penelitian deskriptif analitis, yakni penulis menggunakan data hasil penelitian yang sudah ada sebelumnya dalam bentuk beberapa jurnal yuridis secara penuh. Penelitian ini bersifat deskriptif, yang berarti bahwa penelitian ini bersifat non eksperimental. Penulis tidak melakukan penelitian hukum secara langsung ke lapangan kegiatan usaha perdagangan, namun sesuai dengan data sekunder atau hasil penelitian yang telah dilakukan sebelumnya. Dengan demikian, penyajian data bersifat deskriptif dan analisisnya bersifat kualitatif. 
Hasil dan Pembahasan

Hubungan Hukum antara Makelar dan Komisioner terhadap Pihak Ketiga

Ketika berbicara mengenai perikatan atau hubungan timbal balik yang menyebabkan pemenuhan hak dan kewajiban antara penjual dan pembeli, maka tidak akan terlepas dari prestasi dan wanprestasi. Hubungan hukum antara dua orang atau lebih atau yang biasa disebut dengan perikatan itu menyebabkan pihak yang satu memiliki hak untuk menuntut di mana pihak yang lain mempunyai kewajiban untuk memenuhi tuntutan itu. Hal ini kemudian dikenal dengan istilah utang dan piutang. Pihak yang memiliki hak untuk menuntut sesuatu (pihak yang memiliki piutang) disebut kreditur, sementara pihak yang wajib memenuhi tuntutan (pihak yang berutang) disebut debitur. Dalam Pasal 1234 KUH Perdata(S- et al., n.d.), sesuatu atau barang yang dapat dituntut tersebut disebut dengan "prestasi", yang diserahkan baik karena telah berbuat sesuatu atau tidak berbuat sesuatu.

Dari suatu perikatan, hukum (Undang-Undang) menjamin hak kreditur. Hal ini ditujukan untuk kreditur bahwa ia dapat menuntut di depan hakim (pengadilan) bilamana debitur tidak memenuhi tuntutannya secara sukarela (Timur, 2002). Pihakpihak sangat mungkin untuk tidak selalu memenuhi janjinya dikarenakan lalai atau telah menciderai hubungan hukum sehingga tidak sesuai dengan apa yang telah disepakati bersama, pihak ini disebut pihak yang telah melakukan "wanprestasi". Akibatnya, perikatan yang terjadi di antara kedua belah pihak dapat dibatalkan, pihakpihak yang telah melakukan wanprestasi harus membayar ganti rugi, atau membayar ganti rugi sekaligus pembatalan perikatan, bahkan risiko dapat dialihkan dan membayar biaya perkara jika diperkarakan. Akan tetapi, hal-hal ini tidak dapat diterima begitu saja apabila pihak debitur melakukan pembelaan terhadap dirinya sendiri (karena telah ditetapkan hukum bahwa ia dapat membela diri) dengan disertai bukti atau alasan ia berbuat (Ambarini et al., 2018), misalnya saja membuktikan bahwa pihak kreditur juga lalai, menyertakan alasan di mana saat itu dalam keadaan yang genting, atau dengan membuktikan bahwa pihak kreditur telah melepas tuntutannya dari pihak debitur.

Berhubungan dengan kelalaian, baik yang menimpa pihak kreditur 
maupun pihak debitur dalam ketentuan Pasal 1460 KUH Perdata menjalankan perikatan, ada suatu masa (Review, 2014) kemudian ditetapkan perikatan tidak dapat dilaksanakan bahwa risiko ada di tangan pembeli disebabkan oleh hal-hal yang tidak walaupun belum ada penyerahan dapat diduga sehingga tidak dapat barang dari penjual ke pembeli. Oleh berbuat apapun terhadap kondisi itu. sebab itu, Profesor Subekti Hal ini yang disebut dengan overmacht mengungkap keganjilan yang terjadi atau force majeur. Seseorang atau dari peristiwa hukum ini yang beliau pihak manapun tidak bisa dinyatakan kutip dari code civil Perancis. Beliau sebagai pihak yang lalai dan bersalah. Dengan demikian, pihak tersebut tidak dapat dikenai beban tanggung jawab dan harus terhindar dari penjatuhan sanksi atau hukuman sebagaimana yang telah diatur dalam Pasal 1244 dan 1245 KUH Perdata. Menurut pendapat Profesor Subekti dari kedua pasal ini dapat disimpulkan bahwa akibat suatu hal yang bersifat sangat memaksa, pihak debitur dapat dibebaskan dari beban tanggung jawab dan kewajiban untuk mengganti rugi.(Hughes, 2008)

Hal yang perlu diperhatikan lebih lanjut adalah bilamana dalam keadaan lalai karena overmacht(Islam et al., 2014)pihak debitur tidak dapat melakukan kewajibannya untuk mengganti rugi sesuai dengan UndangUndang, kemudian siapakah pihak yang oleh Undang-Undang akan dibebani untuk mengganti rugi? Hal inilah yang disebut risiko akibat adanya hubungan timbal balik. Dalam menyatakan bahwa keadaan yang terjadi ini adalah wajar karena dalam kegiatan jual beli barang tertentu risiko telah berpindah ke tangan pembeli sesuai dengan kesepakatan bersama atau konsensus meskipun dalam KUH Perdata ditetapkan pada saat terjadi penyerahan barang atau levering.

Manusia sebagai makhluk individu sekaligus sebagai makhluk sosial memiliki banyak kepentingan dalam hidupnya. Mereka saling berhubungan atau berinteraksi satu sama lain untuk memenuhi tuntutan kepentingan yang banyak itu. Mereka juga menyatakan kehendak atau harapan masing-masing dari adanya interaksi atau hubungan tersebut yang merupakan suatu perbuatan atau tindakan hukum. Dari sini, timbul suatu pertukaran atau transfer kepentingan di antara pihak-pihak yang telah melakukan kesepakatan atau pertemuan yang dikehendaki sebelumnya sehingga 
tercipta suatu ikatan yuridikal. Ikatan ini menimbulkan suatu akibat hukum (Calafiore \& Massai, 2017), yang kemudian dapat dilakukan secara langsung di mana kedua belah pihak bertemu dan bersepakat secara langsung, bahkan dapat dilakukan secara tidak langsung dalam hal menggunakan jasa perantaraan (pedagang perantara) untuk menyambungkan ikatan atau hubungan hukum di antara kedua belah pihak.

Dalam tata niaga nasional, hukum privat lebih memfokuskan kepentingan individu atas kepentingan yang disebabkan oleh hubungan hukum antara pelaku usaha dan pedagang perantara. Hubungan yang terjalin di antara para pihak dalam kegiatan perdagangan nasional dapat dilakukan secara tidak langsung melalui pedagang perantara, yaitu dua belah pihak tidak bertatap muka secara langsung. Adapun, perjanjian antara pedagang perantara dan pelaku usaha terjadi akibat adanya kehendak atau harapan atau kepercayaan dari pedagang perantara, makelar dan komisioner, selaku mewakili pelaku usaha kepada pihak ketiga. Dari perikatan ini, sangat mungkin timbul ikatan utang-piutang (Martínez-Cháfer et al., 2018) karena tidak semua barang

dapat dibeli secara tunai sesuai dengan kesepakatan yang telah dibuat sebelumnya. Akibatnya, sementara pihak ketiga berlaku sebagai debitur, pedagang perantara dapat bertindak sebagai seorang kreditur dalam hal penentuan harga barang sesuai dengan perintah dari pelaku usaha yang menyuruhnya.

Para pihak yang membantu perusahaan atau yang biasa dikenaldengan sebutan pedagang perantara, makelar dan komisioner, bekerja di bawah suatu kuasa yang menyertainya. Mereka tidak dapat menjalankan tugasnya tanpa ada kuasa, yang dimaksudkan di sini adalah adanya peristiwa serah dan terima kuasa. Hal ini sangat erat kaitannya dengan isi perjanjian lastgeving atau perjanjian pemberian kuasa antara pemberi, pemegang, dan penerima kuasa. Sayangnya, ketentuan mengenai perjanjian pemberian kuasa ini tidak diatur dalam KUHD, tetapi terdapat di dalam Pasal 16 Buku III KUH Perdata.(Review, 2014) Di dalamnya disebutkan bahwa karena perbuatanperbuatan hukum yang dilakukan oleh pemegang kuasa selalu mengikat pemberi kuasa bilamana si majikan atau pemegang kuasa tidak bertindak 
melampaui batas kuasa dari pemberi kuasa.

Pihak pemegang kuasa, dalam hal ini makelar dan komisoner, mewakili pihak pemberi kuasa sesuai dengan asas perwakilan dalam $\mathrm{KUH}$ Perdata (Ambarini et al., 2018), terutama dalam hal memelihara hubungan dengan pihak ketiga. Asas ini berlaku bagi beberapa pedagang perantara dan tidak berlaku bagi beberapa pedagang perantara, bahkan ketika mereka bertindak demi kepentingan pemberi kuasa sekali pun. Misalnya saja berlaku bagi pedagang keliling yang bertindak atas nama pemberi kuasa dan berlaku bagi agen perusahaan yang tidak menjabat di bawah perusahaan. Selanjutnya, asas ini tidak berlaku bagi seorang komisioner yang bertindak atas nama sendiri walaupun bekerja untuk kepentingan suatu perusahaan atau pemberi kuasa. Dengan demikian dapat disimpulkan bahwa terdapat perbedaan kewajiban dari beberapa pedagang perantara, yang kemudian dapat dianalisis oleh penulis dalam uraian selanjutnya.
Perbedaan Bentuk Tanggung Jawab antara Makelar dan Komisioner terhadap Pihak Ketiga

\section{A. Makelar}

Pengaturan mengenai makelar diatur dalam Pasal 62 sampai dengan 73 Bagian Kedua Bab Keempat Kitab Undang-Undang Hukum Dagang atau disingkat KUHD. Pasal 62 KUHD mengartikan seorang pedagang perantara yang diangkat oleh presiden atau pembesar yang telah dinyatakan berwenang oleh presiden sebagai makelar. (Kepmenperindag No. 23 Th. 1998 tentang Lembaga-lembaga Usaha Perdagangan.pdf, n.d.) Sebelum diizinkan bekerja untuk perusahaan, seorang makelar harus diangkat oleh pejabat yang berwenang terlebih dahulu. Hal ini harus dilakukan dengan maskud untuk menyumpah yang bersangkutan di hadapan ketua pengadilan negeri di mana yang bersangkutan tinggal. Setelah dilakukan sumpah demikian, di masa depan, hasil dari pekerjaannya sebagai makelar disebut sebagai provisi di mana yang bersangkutan bekerja untuk dan atas nama orang lain.(Bisnis et al., n.d.)

Fakta demi fakta yang terjadi di lapangan berbeda dari apa yang telah disebutkan dalam Pasal 62 KUHD. 
Misalnya di lapangan Bursa Efek, melakukan pemindahan catatan yang ketentuan yang telah diatur dalam Pasal telah dibuat olehnya ke dalam buku 62 KUHD tidak dapat ditemui lagi harian dengan tingkat ketelitian yang (Upaya et al., 2007). Pedagang sangat tinggi (Setyarsih, 2017). Jadi, perantara di Bursa Efek tidak buku saku adalah buku yang digunakan memerlukan sumpah untuk untuk membuat catatan yang bersifat pengangkatan yang dilakukan di sementara sebelum pada akhirnya hadapan ketua pengadilan negeri di secara permanen atau tetap mana ia akan melakukan pekerjaannya. dipindahkan dan dicatat di dalam buku Kemudian bagi perusahaan sebagai harian. pedagang perantara, harus memenuhi persyaratan minimal memiliki seorang karyawan dan seorang direktur yang telah menmperoleh ijin sebagai pedagang perantara secara orang perseorangan. Akan tetapi sebelum menjalankan pekerjaannya, pedagang perantara tersebut tetap wajib mendapat ijin dari Bapepam.

Setiap makelar memiliki beberapa kewajiban dalam menjalankan pekerjaannya sebagai pedagang perantara sebagaiman yang telah disebutkan dalam KUHD. Adapun kewajiban dari makelar tersebut adalah mempunyai buku harian dan buku saku. Buku-buku itu digunakan untuk mencatat setiap peristiwa hukum atau suatu perjanjian apapun yang telah ditimbulkan olehnya selaku pedagang perantara. Dalam Pasal 66 KUHD juga telah disebutkan bahwa seorang makelar harus

Selain kewajiban yang telah disebut di atas, seorang makelar juga memiliki kewajiban untuk menyimpan barang dari kegiatan jual beli. Adapun yang dimaksud barang di sini adalah barang yang digunakan sebatas sebagai sampel saja yang ia tunjukkan kepada pihak ketiga sebelum akhirnya ada kata sepakat. Penyimpanan barang tersebut oleh makelar dilakukan sampai kegiatan jual beli di mana ia terlibat di dalamnya telah selesai.(Setyarsih, 2017) Misalnya saja, seorang makelar yang menjadi perantara dalam kegiatan jual beli surat-surat berharga berupa wesel, ia harus menanggung keabsahan tanda tangan penjual. Keabsahan tanda tangan penjual inilah yang dapat meyakinkan pembeli atau pihak ketiga untuk membeli barang karena barang telah pasti hukumnya.

Berdasarkan KUHD, dalam melakukan kegiatan perantaraannya, 
makelar juga diberi larangan. jual beli, hanya sebagai yang Melakukan usaha perniagaan dalam memperantarainya.

lapangan perusahaan yang sama di

Pertanggungjawaban makelar mana ia diangkat merupakan larangan dalam usaha perniagaan atau kegiatan bagi makelar. Hal ini dimaksudkan jual beli pada awalnya disebabkan oleh agar makelar tersebut tidak disebut pihak ketiga yang mengalami kerugian. sebagai seorang yang menjual emas di Kerugian-kerugian itu dapat berupa pusat perbelanjaan berlian. Adapun cacat tersembunyi dan tidak aman larangan lainnya adalah ia dilarang hukum atas suatu barang yang telah untuk menjadikan dirinya sendiri dibelinya. (Upaya et al., 2007) Untuk sebagai penjamin dalam perjanjian mendapatkan keadilan dari kasus ini, yang dihubungkannya. Pelarangan ini maka pihak ketiga dapat mengajukan sebagaimana yang telah diatur dalam komplain kepada pihak penjual Pasal 65 ayat 2 KUHD(Islam et al., (pengusaha). Mengapa mengkomplain 2014).

Hubungan hukum antara pengusaha, bukan makelar selaku perantara barang? Karena yang makelar dan pengusaha (penjual) dapat diilustrasikan dalam penjelasan berikut ini. Seorang pengusaha A menyuruh seorang makelar B untuk menjualkan hasil produksinya sehingga $\mathrm{B}$ menjualkannya kepada pihak ketiga (pembeli) C. Hubungan hukum A dan B berdasarkan hubungan kuasa yang diatur dalam Pasal 62 KUHD (S- et al., n.d.), di mana A merupakan pemberi kuasa dan $\mathrm{B}$ adalah pemegang atau penerima kuasa. Akibatnya, B dalam menjualkan produk kepada $\mathrm{C}$ bertindak untuk dan atas nama A. Dengan demikian, B tidak termasuk di dalam pihak-pihak yang melakukan kegiatan memiliki status sebagai penjual adalah si pengusaha, bukan si makelar. Dalam hal ini, makelar sebatas berbuat untuk dan atas nama pengusaha, sertaberada di luar pihak-pihak yang melakukan kegiatan jual beli.(Kasmawati et al., 2018)

Berdasarkan fakta yang ada, tindakan makelar dalam menjualkan barang milik pengusaha merupakan suatu kegiatan yang dilakukan secara rutin. Namun, ada satu kondisi dimana tidak ada perbuatan serah dan terima antara pengusaha dan makelar karena si pengusaha merupakan pelanggannya dan berada di luar kota. Lalu, si makelar tetap menjualkan barang itu 
karena kebiasaan yang ditimbulkan dari hubungan tersebut. Bilamana setelahnya ada komplain dari pihak ketiga, maka yurisprudensi memutuskan dan menetapkan bahwa makelar lah yang harus bertanggung jawab. (Bisnis et al., n.d.) Mengapa makelar? Alasannya adalah karena ia bertindak sebagai penjual ketika berlangsungnya kegiatan jual beli.

Dalam praktik di lapangan, seringkali makelar melakukan perbuatan hukum tanpa didahului pengangkatan dan sumpah di hadapan ketua pengadilan negeri tempat ia akan bekerja. Selain itu, tidak adanya pengikatan terhadap kewajiban dan larangan makelar sebagaimana diatur dalam KUHD juga sering terjadi. Kemudian, Guru Besar Hukum Dagang Universitas Indonesia, Sukardono, menyebut makelar seperti itu adalah makelar liar. Liar di sini diartikan dengan pemberian provisi yang dilakukan sesuai dengan kesepakatan awal sebelum makelar bekerja dan berlandaskan ketentuan kuasa dalam KUHD. (Bisnis et al., n.d.) Karena masih dikatakan sebagai makelar, si makelar tetap harus bertanggung jawab kepada pihak ketiga yang mengalami kerugian.

\section{B. Komisioner}

Pengaturan tentang komisoner diatur dalam Pasal 76 sampai dengan 85a Bagian Kesatu Bab Kelima Kitab Undang-Undang Hukum Dagang atau disingkat KUHD. Pasal 76 KUHD menjelaskan komisioner sebagai seorang penyelenggara perusahaan dengan membuat perjanjian atas nama atau firma sendiri, namun atas amanat dan tanggungan orang lain dan mendapat provisi sebagai upahnya. (Kepmenperindag No. 159 Th. 1998 tentang Perubahan Kepmenperindag No. 23 Th. 1998 tentang Lembagalembaga Usaha Perdagangan.pdf, n.d.) Komisioner tidak memerlukan pengangkatan dan sumpah seperti makelar. Selain itu, komisioner juga tidak diberi kewajiban dan larangan sebagaimana yang harus ada dalam kegiatan makelar. Dari sinilah kita dapat mencari perbedaan antara makelar dan komisoner, terutama dalam hal pertanggungjawaban kepada pihak ketiga.(Hughes, 2008)

Komisioner diberikan beberapa hak khusus oleh Undang-Undang (UU) yang disebut hak retensi dan hak istimewa. Adapun hak retensi dalam Pasal 85 KUHD diartikan dengan hak untuk melakukan penahanan atas barang-barang milik komiten. (S- et al., 
n.d.) Ia berhak untuk menahan barangbarang tersebut sampai komiten membayar komisi dan biaya-biaya yang telah dikeluarkannya. Sedangkan hak istimewa yang disebut dalam Pasal 81, 82, dan 83 KUHD merupakan hak untuk menjual barang-barang milik komiten yang tidak mengindahkan hak retensi komisioner.(Review, 2014) Dalam hal ini, ia bukanlah pemilik barang dan tanpa kuasa, namun berhak untuk menjual barang-barang tersebut sampai ia memperoleh pelunasan dari komiten.

Hubungan hukum antara komisioner dan pengusaha yang lazimnya disebut komiten tidak sama persis dengan hubungan hukum antara makelar dan pengusaha. (Ambarini et al., 2018) Berikut ini adalah ilustrasi hubungan hukum antarpihak dalam kegiatan jual beli melalui komisioner. Seorang pengusaha A menyuruh seorang komisioner B untuk menjualkan produknya sehingga $B$ menjualkannya kepada pihak ketiga (pembeli) C. Dalam hubungan ini berdasarkan Pasal 76 KUHD(Review, 2014), B menjual barang kepada C tidak untuk dan atas nama A, tetapi untuk dan atas nama sendiri. Jadi, hal ini tampak tidak ada hubungan hukum antara A dan B.
Hubungan hukum antara A dan B di atas akan berbeda jika hubungan hukum di mana $\mathrm{B}$ bertindak kepada $\mathrm{C}$ karena disuruh oleh A. Hubungan antara B dan C adalah kuasa, demikian pula hubungan hukum antara B dan A adalah lembaga kuasa, di mana A merupakan pemberi kuasa dan B adalah pemegang atau penerima kuasa. Oleh sebab itu, undang-undang tidak mengatur perjanjian komisi ini, hanya saja para pakar menyebutnya sebagai pemberian kuasa khusus.(Swastiwi, n.d.) Arti khusus di sini ada pada perbuatan B selaku penerima kuasa yang dapat berbuat untuk dan atas nama sendiri. Padahal umumnya terhadap pihak ketiga, penerima kuasa berbuat untuk dan atas nama pemberi kuasa.

Dari hubungan-hubungan di atas, penerima kuasa dapat berbuat mewakili diri sendiri di samping mewakili komiten. Arti mewakili diri sendiri di sini adalah diperbolehkannya membeli barang milik pemberi kuasa ketika pemberi kuasa menuruhnya untuk menjualkannya. Sebaliknya, penerima kuasa juga boleh menjual barang milik sendiri pada saat pemberi kuasa memerintahnya untuk membelikan suatu barang. Akan tetapi, bilamana B berbuat sebagai komisioner 
di bawah tangan, maka ia akan maupun antara pihak perantara dan kehilangan status sebagai pedagang pihak pengusaha. Akibat dari hubungan perantara. Ketentuan boleh dan hukum ini, maka dapat ditentukan tidaknya perbuatan $\mathrm{B}$ ini diatur dalam pihak-pihak yang wajib untuk memikul Pasal 1470 KUH Perdata (Swastiwi, tanggung jawab terhadap pihak ketiga n.d.).

Tanggung jawab seorang yang dirugikan. Hubungan hukum baik komisioner kepada pihak ketiga dalam berhubungan dengan komiten antara pihak makelar dan pihak pengusaha maupun antara pihak (pengusaha) dapat diminta oleh pihak komisioner dan pihak ketiga sangat berpengaruh terhadap penentuan pihakketiga tersebut (Review, 2014). pihak yang wajib bertanggung jawab Pertanggungjawaban itu berdasarkan atas barang-barang yang memiliki cacat atas suatu barang yang tidak aman hukum dan memiliki cacat yang tidak tersembunyi dan tidak aman hukum.

Poin-poin penting terkait diketahui oleh pihak ketiga ketika hubungan hukum dan tanggung jawab membelinya. Dikarenakan hubungan dari makelar dan komisioner: hukum yang terjadi hanya ada pada hubungan hukum antara makelar dan pihak komisioner dan pihak ketiga, pihak ketiga merupakan hubungan maka yang wajib menanggung beban hukum kuasa berdasarkan pemberian atau tanggung jawab adalah pihak kuasa, hubungan hukum komisioner itu sendiri. Ia bekerja untuk antarakomisioner dan pihak ketiga dan atas nama sendiri. Terlebih, ketika adalah hubungan hukum kuasa atas melakukan transaksi jual beli barang perintah dari komiten, makelar tidak dengan pihak ketiga, ia sendiri yang bertanggung jawab atas barang yang bertindak sebagai penjual walaupun memiliki cacat tersembunyi dan tidak tetap mewakili pihak pengusaha atau aman hukum, serta komisoner komiten.

\section{Kesimpulan}

Hubungan hukum melalui bertanggung jawab secara langsung atas barang yang memiliki cacat pedagang perantara, khususnya tersembunyi dan tidak aman hukum makelar dan komisioner ditentukan karena ia bertindak untuk dan atas oleh hubungan hukum baik antara kepada pihak ketiga. pihak perantara dan pihak ketiga 


\section{Daftar Pustaka}

Ambarini, N. S. B., Sofyan, T., \& Satmaidi, E. (2018). Hubungan Hukum Pedagang Perantara Dan Pelaku Usaha Dalam Bisnis Perikanan Nasional. Jurnal Hukum \& Pembangunan, 48(4), 743. https://doi.org/10.21143/jhp.vol48 .no4.1801

Aytac, S., Bayram, N., Özenalp, A., Özgökçeler, S., Berkun, S., Ceylan, A., \& Erturk, H. (2012). Flexible Working and Employment of People with Disabilities at Customs Brokerage Firms in Turkey: A Social Responsibility Project. Procedia Social and Behavioral Sciences, 65(ICIBSoS), 39-45. https://doi.org/10.1016/j.sbspro.20 12.11.088

Bisnis, H., Hukum, F., \& Udayana, U. (n.d.). Hak dan kewajiban makelar dalam perjanjian dagang. 1-5.

Calafiore, G. C., \& Massai, L. (2017). Control of Brokerage Margins. IFAC-PapersOnLine, 50(1), 12279-12284.

https://doi.org/10.1016/j.ifacol.20 17.08.2471

Christopoulos, D., \& Ingold, K. (2011). Distinguishing between political brokerage \& political entrepreneurship. Procedia Social and Behavioral Sciences, 10, 36-42. https://doi.org/10.1016/j.sbspro.20 11.01 .006

Francisco, A. R. L. (2013). 済無No Title No Title. Journal of Chemical Information and Modeling, 53(9), 1689-1699. https://doi.org/10.1017/CBO9781
107415324.004. (2013)。済無No

Title No Title. Journal of Chemical Information and Modeling, 53(9), 1689-1699. https://doi.org/10.1017/CBO9781 107415324.004

Islam, U., Sunan, N., Yogyakarta, K., Memenuhi, U., Syarat, S. S.-, Gelar, M., Strata, S., Ilmu, D., \& Islam, H. (2014). Tinjauan hukum islam terhadap praktek kemakelaran dalam jual beli sepeda motor (studi kasus di desa ngerangan bayat klaten).

Jurnal Law Review - Vol. 3 No. 1, Februari 2014 71. (2014). 3(1).

Kandjani, H., Wen, L., \& Bernus, P. (2012). Enterprise architecture cybernetics for collaborative networks: Reducing the structural complexity and transaction cost via virtual brokerage. In IFAC Proceedings Volumes (IFACPapersOnline) (Vol. 14, Issue PART 1). IFAC. https://doi.org/10.3182/201205233-RO-2023.00162

Kasmawati, A., Suhaeb, I. D. S., \& Herman. (2018). Hukum Dagang.

Martínez-Cháfer, L., Molina-Morales, F. X., \& Peiró-Palomino, J. (2018). The cluster is not flat. Uneven impacts of brokerage roles on the innovative performance of firms. $B R Q$ Business Research Quarterly, 21(1), 11-25. https://doi.org/10.1016/j.brq.2017. 12.002

Melvin, M., \& Wen, L. (2013). The choice of direct dealing or electronic brokerage in foreign exchange trading. Borsa Istanbul Review, 13(3), 10-21. https://doi.org/10.1016/j.bir.2013. 
10.005

Ningsih, A. S. (n.d.). BADAN USAHA.

Perusahaan, P. (n.d.). Perdagangan dan Perusahaan. 1-54.

Review, J. L. (2014). Jurnal Law Review - Vol. 3 No. 1, Februari 2014. 3(1).

S-, B. P. P., Studi, P., Ekonomi, H., Syari, F., Uin, H., Ampel, S., \& Penulis, S. (n.d.). Hukum dagang.

Setyarsih, E. (2017). Fenomena Makelar Kost dalam Sudut Pandang Sosio-Ekonomi Ditinjau dari Teori Pertukaran Peter Michael Blau. Jurnal Analisa Sosiologi, 6(2), 76-90.

Swastiwi, A. W. (n.d.). Pedagang Perantara Cina.Pdf.

Syarifin, P., \& Jubaedah, D. (2012). Hukum Dagang Di Indonesia. Jurnal Media Hukum Dan Peradilan, 6, 456.
pes-Rios, B., Gonzalez-Tapia, K., \& Gonzalez-Perez, M. A. (2015). The integration of stock exchanges: The case of the Latin American Integrated Market (MILA) and its impact on ownership and internationalization status in Colombian brokerage firms. Journal of Economics, Finance and Administrative Science, 20(39), 84-93. https://doi.org/10.1016/j.jefas.201 5.08 .001

Yustiana, A., Pertanian, F., \& Maret, U. S. (2010). SIKAP PETANI $M E L O N$ TERHADAP 